\title{
Rebiopsy of Histological Samples in Pretreated Non-small Cell Lung Cancer: Comparison Among Rebiopsy Procedures
}

\author{
AKITO HATA ${ }^{1}$, NOBUYUKI KATAKAMI ${ }^{1}$, SHIGEKI NANJO ${ }^{1}$, \\ CHIYUKI OKUDA ${ }^{1}$, REIKO KAJI $^{1}$ and YUKIHIRO IMAI ${ }^{2}$ \\ ${ }^{1}$ Division of Integrated Oncology, Institute of Biomedical Research and Innovation Hospital, Kobe, Japan; \\ ${ }^{2}$ Department of Clinical Pathology, Kobe City Medical Center General Hospital, Kobe, Japan
}

\begin{abstract}
Aim: The aim of the present study was to compare successful rate, failure reasons, and complications among procedures of histological rebiopsy. Patients and Methods: We retrospectively reviewed medical records of histologically rebiopsied cases with non-small cell lung cancer. Results: One hundred and eleven histological rebiopsies were performed in: 86 (77\%) lung; 11 (10\%) lymph node; 5 (5\%) pleura; 4 (4\%) liver; 2 (2\%) muscle; 2 (2\%) adrenal gland; and 1 (1\%) rib. Successful rate by computed tomography-guided biopsy $(C T G B)$, transbronchial biopsy (TBB), and ultrasound-guided biopsy were 86\% (48/56), 90\% (28/31), and 100\% (24/24), respectively. Reasons for rebiopsy failure by CTGB were no/insufficient malignant cells $(n=5)$ and pneumothorax $(n=3)$, and those by TBB were no/insufficient malignant cells $(n=2)$ and bleeding $(n=1)$. Severe complications ( $\geq$ grade 3$)$ : one grade 3 pneumothorax and one grade 4 air embolization were observed in two $(2 \%, 2 / 111)$ cases receiving CTGB. Conclusion: Rebiopsy of histological samples can be highly successful and feasible by optimal procedural selection.
\end{abstract}

Lung cancer is the leading cause of cancer-related deaths worldwide. Non-small cell lung cancer (NSCLC) accounts for approximately $80 \%$ of lung cancers, and the majority are already unresectable and metastatic upon their initial diagnosis. Cytotoxic chemotherapies such as platinum-based regimens were once the primary therapeutic option for metastatic NSCLC, but their advancement has reached a plateau. Molecular-targeted therapies have been recently

This article is freely accessible online.

Correspondence to: Akito Hata, Division of Integrated Oncology, Institute of Biomedical Research and Innovation, 2-2, Minatojimaminamimachi, Chuo-ku, Kobe, 650-0047, Japan. Tel: +81 783045200, Fax: +81 783021708, e-mail: a-hata@fbri.org.

Key Words: Rebiopsy, histology, non-small cell lung cancer. developed, and they have provided a remarkable benefit to patients harboring specific genetic alterations such as epidermal growth factor receptor (EGFR) gene mutations or anaplastic lymphoma kinase (ALK) gene fusions (1-3). Efficacies of up-front EGFR- and ALK-tyrosine kinase inhibitors (TKIs) have been established for patients harboring these genetic alterations in prospective randomized phase III trials comparing platinum doublets, and the median progression-free survivals (PFSs) are approximately 12 months $(4,5)$. Despite an initial dramatic response, most patients receiving these TKIs finally acquire resistance.

Several acquired resistant mechanisms to EGFR-TKIs have been identified (6-9), and the "gatekeeper" EGFR mutation, a threonine-to-methionine substitution at amino acid position 790 in exon 20 (T790M), is the most common mechanism and accounts for more than half of acquired resistance to EGFR-TKIs (10). Therefore, it is clinically important to develop more effective therapies for patients with T790M. Indeed, third-generation EGFR-TKIs have been developed, and have demonstrated their remarkable efficacies for patients with T790M $(11,12)$. Because a thirdgeneration EGFR-TKI is indicated only in cases where histological samples reveal T790M, histological rebiopsy to confirm T790M status becomes essential in clinical practice for patients after acquired resistance to EGFR-TKIs.

On the other hand, current advancement of immunotherapies is evolving. Among them, anti-programmed death-1 (PD-1)/ programmed death-ligand 1 (PD-L1) antibodies have demonstrated their notable efficacies in pretreated NSCLC. Anti-PD-1 antibodies, nivolumab, pembrolizumab and atezolizumab have shown survival benefit compared to docetaxel monotherapy in pretreated patients with NSCLC after failure of platinum doublet chemotherapies in randomized phase III trials (13-16). Based on results of these trials, antiPD-1 antibody monotherapies have become standard treatments for pretreated NSCLC.

In cases responding to such immunotherapies, durable response is expected over 1-2 years, much longer than 
common cytotoxic agents (13-16). Unfortunately, the response rate and PFS of these immunotherapies are generally $10-20 \%$ and 2-3 months, respectively, and relatively many patients obtain no response and experience early progression. Thus, reliable predictive markers are needed for better patient selection.

Several predictive markers for anti-PD-1/PD-L1 antibodies have been developed. Among them, PD-L1 expression is the most widely investigated predictive marker for many types of cancers. Some studies for NSCLC have demonstrated correlations between PD-L1 expression and response to anti-PD-1/PD-L1 antibodies (14-17). PD-L1 expression is commonly examined by immunohistochemistry (IHC) for histological samples. Moreover, PD-L1 expression can be temporally dynamic (18), and rebiopsied histological samples may be desirable before PD-L1 IHC examinations.

Based on the above background, rebiopsy of histological sample is necessary to confirm T790M/PD-L1 status. However, histological rebiopsy is an invasive manner, and tissue availability and procedural feasibility make it more challenging, resulting in limited data focusing on histological rebiopsy. We thus reviewed pretreated NSCLC cases receiving rebiopsy of histological samples at our institutes.

\section{Patients and Methods}

Patients. We retrospectively screened electronic medical records of patients with NSCLC who had received histological rebiopsies in our institutes (Institute of Biomedical Research and Innovation [IBRI], Japan and Kobe City Medical Center General Hospital [KCGH] , Japan). The study was approved by the institutional review board, and complied with the Declaration of Helsinki.

Rebiopsy. Rebiopsies were performed on various sites using various procedures. Computed tomography-guided biopsy (CTGB) (using percutaneous core needle), transbronchial biopsy (TBB) with flexible bronchoscopy, or ultrasound-guided biopsy (USGB) (using percutaneous core needle) were used as rebiopsy procedures after obtaining appropriate written informed consent. Some patients underwent multiple (sites and/or times) rebiopsies.

T790M and PD-L1 expression analyses. We isolated tumor DNA from each specimen, and analyzed EGFR sensitive mutations and T790M mutation using highly sensitive assays: the peptide nucleic acid-locked nucleic acid PCR clamp method or the cycleave method $(19,20)$. In patients who were enrolled to clinical trials of a third-generation EGFRTKI, we sent histological samples to central laboratories of each trial, and they were examined using the cobas EGFR Mutation Test (11).

PD-L1 expression was analyzed only in patients who were enrolled in clinical trials of anti-PD-1/PD-L1 antibodies. These clinical trials routinely demanded histological samples, but the results were not always reported to doctors in charge. Central laboratories of each trial analyzed PD-L1 expression, and we knew only whether PD-L1 expression analysis was successful or not.

End-point. The aim of this study was to investigate successful rate, failure reasons, and major complications of rebiopsy, according to
Table I. Patient characteristics.

\begin{tabular}{lc}
\hline Characteristics (n=81) & Number $(\%)$ \\
\hline Age & \\
$\quad$ Median (range) & $65(26-84)$ \\
Gender & \\
$\quad$ Male & $37(46 \%)$ \\
Female & $44(54 \%)$ \\
Smoking status & \\
Never & $32(40 \%)$ \\
Ever & $49(60 \%)$ \\
Histology & \\
Adeno & $71(88 \%)$ \\
Squamous & $8(10 \%)$ \\
LCNEC & $2(2 \%)$ \\
Genotype & $60(74 \%)$ \\
EGFR-mutated & $1(1 \%)$ \\
ALK-fusioned & $20(25 \%)$ \\
Wild-type & \\
Frequency of rebiopsy & $58(72 \%)$ \\
1 & $19 / 2 / 1 / 1(28 \%)$ \\
$2 / 3 / 4 / 5$ &
\end{tabular}

LCNEC, Large-cell neuroendocrine carcinoma; EGFR, epidermal growth factor receptor; ALK, anaplastic lymphoma kinase.

each procedure. Successful rebiopsy was defined as obtaining sufficient malignant cells to examine T790M status or PD-L1 expression. Major complications were graded by Common Terminology Criteria for Adverse Events (CTCAE) version 4.0.

\section{Results}

Sample and patient characteristics. One-hundred and eleven histological rebiopsies were performed in 81 NSCLC patients between January 2010 and October 2015 at IBRI or KCGH. Patient characteristics are shown in Table I. Median age was 65 (range=26-84) years. Histologies included: 71 $(88 \%)$ adenocarcinomas; 8 (10\%) squamous cell carcinomas; and $2(2 \%)$ large cell neuroendocrine carcinomas. Patient gene profiles were: 60 (74\%) EGFR-mutant; 1 (1\%) ALKfusion; and 20 (25\%) EGFR/ALK wild-type. Twenty-three $(28 \%)$ patients underwent rebiopsy more than two times.

The purposes of rebiopsies were to examine: T790M status $(66 / 111,59 \%)$; PD-L1 expression $(25 / 111,23 \%)$; or both $(20 / 111,18 \%)$.

Rebiopsy site and procedure. Rebiopsy was performed in: 86 (77\%) lung; 11 (10\%) lymph node (LN); 5 (5\%) pleura; 4 (4\%) liver; 2 (2\%) muscle; 2 (2\%) adrenal gland; and $1(1 \%)$ rib (Table II). Most rebiopsies were performed in lung lesions $(86 / 111,77 \%)$, whereas approximately one-fourth $(25 / 111,23 \%)$ were extra-lung.

In $6(5 \%)$ of 111 rebiopsies whose target lesions were difficult for us to carry out (4 liver, $1 \mathrm{LN}$, and 1 adrenal 
Table II. Details of rebiopsy.

\begin{tabular}{|c|c|c|c|}
\hline Institute & Procedure & Location & $\begin{array}{l}\text { Successful } \\
\text { rate }\end{array}$ \\
\hline \multirow[t]{10}{*}{ IBRI (n=105) } & CTGB $(n=55)$ & $\begin{array}{l}\text { Lung }(n=50) \\
\text { Pleura }(n=5)\end{array}$ & $85 \%(47 / 55)$ \\
\hline & TBB $(n=31)$ & Lung $(\mathrm{n}=31)$ & \multirow[t]{4}{*}{$90 \%(28 / 31)$} \\
\hline & \multirow[t]{8}{*}{ USGB $(n=19)$} & $\mathrm{LN}(\mathrm{n}=10):$ & \\
\hline & & $\begin{array}{c}\text { Cervical }(n=4) ; \\
\text { Supraclavicular }(n=3)\end{array}$ & \\
\hline & & Mediastinal $(\mathrm{n}=1)$ & \\
\hline & & $\begin{array}{l}\text { Axillary }(\mathrm{n}=1) ; \text { and } \\
\text { Inguinal }(\mathrm{n}=1)\end{array}$ & \multirow[t]{5}{*}{$100 \%(19 / 19)$} \\
\hline & & Lung $(\mathrm{n}=5)$ & \\
\hline & & Muscle $(n=2)$ & \\
\hline & & $\operatorname{Rib}(n=1)$ & \\
\hline & & Adrenal gland $(\mathrm{n}=1)$ & \\
\hline \multirow[t]{3}{*}{ KCGH $(n=6)$} & USGB $(n=5)$ & Liver $(n=4)$ & \multirow[t]{2}{*}{$100 \%(5 / 5)$} \\
\hline & & Axillary LN $(n=1)$ & \\
\hline & CTGB $(n=1)$ & Adrenal gland $(\mathrm{n}=1)$ & $100 \%(1 / 1)$ \\
\hline
\end{tabular}

IBRI, Institute of Biomedical Research and Innovation; CTGB, computed tomography-guided biopsy; TBB, transbronchial biopsy; USGB ultrasound-guided biopsy; LN, lymph node; and KCGH; Kobe City Medical Center General Hospital.

gland), we asked another cooperating institute (KCGH) to perform rebiopsies (Table II).

Successful rate. Overall successful rate of rebiopsy was $90 \%$ (100/111). Successful rate by CTGB, TBB, and USGB were $86 \%$ (48/56), 90\% (28/31), and 100\% (24/24), respectively.

Reasons for rebiopsy failure. Table III shows reasons for rebiopsy failure by each procedure. Reasons for rebiopsy failure by CTGB $(n=8)$ were no or insufficient malignant cells $(n=5)$ and pneumothorax during procedure before biopsy $(n=3)$, and those by TBB $(n=3)$ were no or insufficient malignant cells $(n=2)$ and bleeding during procedure before biopsy $(n=1)$. All USGBs were successful.

Major complications. Lower Table III shows major complications by each procedure. In cases receiving CTGB, $3(3 / 56,5 \%)$ grade 1 and $7(7 / 56,13 \%)$ grade 2 bleeding, 14 $(14 / 56,25 \%)$ grade $1,1(1 / 56,2 \%)$ grade 2 , and $1(1 / 56,2 \%)$ grade 3 pneumothorax, and $1(1 / 56,2 \%)$ grade 4 air embolization were confirmed in a total of $25(25 / 56,45 \%)$ cases. In cases receiving TBB, $12(12 / 31,39 \%)$ grade 1 and $9(9 / 31,29 \%)$ grade 2 bleeding were observed in a total of $21(21 / 31,68 \%)$ cases. There were no major complications in USGB cases. Severe complications ( $\geq$ grade 3 ): one grade 3 pneumothorax and one grade 4 air embolization were observed in $2(2 \%, 2 / 111)$ cases receiving CTGB.
Table III. Reasons for failure and major complications.

\begin{tabular}{lccc}
\hline & $\begin{array}{c}\text { CTGB } \\
(\mathrm{n}=56)\end{array}$ & $\begin{array}{c}\text { TBB } \\
(\mathrm{n}=31)\end{array}$ & $\begin{array}{c}\text { USGB } \\
(\mathrm{n}=24)\end{array}$ \\
\hline Reasons for failure & & & \\
No or insufficient malignant cells & $5(9 \%)$ & $2(6 \%)$ & $0(0 \%)$ \\
Pneumothorax & $3(5 \%)$ & $0(0 \%)$ & $0(0 \%)$ \\
Bleeding & $0(0 \%)$ & $1(3 \%)$ & $0(0 \%)$ \\
Total & $8(14 \%)$ & $3(10 \%)$ & $0(0 \%)$ \\
Major complications & & & \\
Bleeding & & & \\
$\quad$ Grade 1 & $3(5 \%)$ & $12(39 \%)$ & $0(0 \%)$ \\
$\quad$ Grade 2 & $7(13 \%)$ & $9(29 \%)$ & $0(0 \%)$ \\
Pneumothorax & & & \\
$\quad$ Grade 1 & $14(25 \%)$ & $0(0 \%)$ & $0(0 \%)$ \\
$\quad$ Grade 2 & $1(2 \%)$ & $0(0 \%)$ & $0(0 \%)$ \\
$\quad$ Grade 3 & $1(2 \%)$ & $0(0 \%)$ & $0(0 \%)$ \\
Air embolization & & & \\
$\quad$ Grade 4 & $1(2 \%)$ & $0(0 \%)$ & $0(0 \%)$ \\
Total & $25(45 \%) *$ & $21(68 \%)$ & $0(0 \%)$ \\
\hline
\end{tabular}

CTGB, Computed tomography-guided biopsy; TBB, transbronchial biopsy; USGB ultrasound-guided biopsy. *Both bleeding and pneumothorax occurred in two cases.

\section{Discussion}

In order to confirm T790M status and/or PD-L1 expression, rebiopsy of histological samples will become more common in our clinical practice. Approval of third-generation EGFRTKIs and anti-PD-1/PD-L1 antibodies will make rebiopsy more essential. In our institute, the number of rebiopsies has been increasing in patients with $E G F R$-sensitive mutations, to enroll clinical trials of third-generation EGFR-TKIs. Moreover, rebiopsy has been performed even in patients without driver oncogene alterations to examine PD-L1 expression before clinical trials. Indeed, twenty (25\%) of 81 patients were $E G F R / A L K$ wild-type and underwent rebiopsy to confirm PD-L1 expression. Until development and spread of liquid biopsy, rebiopsy is necessary to confirm gene alterations and protein expressions.

Overall successful rate of rebiopsy was $90 \%$, and those by CTGB, TBB, and USGB were $86 \%, 90 \%$, and $100 \%$, respectively. We selected the most suitable procedure to successfully obtain histological samples. Since USGB was performed only in easy cases whose targetable lesions were large enough to detect by US, it was natural that the successful rate was extremely high. Successful rate of CTGB was similar to TBB, but this result was highly biased. TBB could be done only in cases whose targetable lesions were confirmed by X-ray fluoroscopy. CTGB was generally adopted to peripheral small nodules which were too difficult for TBB to hit. On the other hand, CTGB is not indicated to 
central located lesions where TBB is the best procedure. It is important to select the most suitable procedure, by taking tumor size, location, and organ into consideration.

Most rebiopsies were performed in lung lesions $(86 / 111$, $77 \%)$, whereas approximately one-fourth $(25 / 111,23 \%)$ were in extra-lung. This result suggests that clinical physicians should prepare rebiopsy for extra-lung lesions. Some of our physicians can perform rebiopsy using CTGB, TBB, and USGB by ourselves. However, in 5 (5\%) of 111 rebiopsies whose target lesions were difficult for us to carry out, we asked another cooperating institute (KCGH) to perform rebiopsy. Some of these 5 patients were enrolled into a clinical trial of third-generation EGFR-TKI, and were able to benefit from the agent in its trial. In Japan, patients with lung cancer are commonly treated by thoracic oncologists/respiratory physicians. TBB is relatively easily and competently carried out by them, but other procedures are not so familiar. Thus, it is important to establish a cooperative system to ask other departments/institutes for optimal procedures which are difficult to be done in original departments/institutes.

We examined major complications with rebiopsy according to each procedure. There were no major complications in USGB cases, because USGB was performed only in easy cases whose targetable tumors were superficial and large enough to be detect by US. TBB recorded $68 \%$ of bleedings, but all were less than grade 2 and manageable, suggesting a safe procedure. CTGB revealed several complications $(45 \%)$, including 2 severes: grade 3 pneumothorax and grade 4 air embolization. Particularly, air embolization is rare, but a possible fatal complication with CTGB. A pooled case study reported that air embolization was confirmed in $6(0.06 \%)$ of 9,783 cases, and 1 of these 6 was fatal (21). CTGB could have a high successful rate and obtain a sufficient tissue, whereas a rare fatal complication such as air embolization should be noted.

Rebiopsy of histological samples includes several disadvantages regarding invasiveness, convenience, and feasibility. As we described above, rare but fatal complications could occur in histological rebiopsy. The more difficult targeted lesions, the more time and effort are taken, resulting in lower feasibility. Notably, liquid biopsy has been currently developed, and this technique can perform rebiopsy, non-invasively. Revolutionaly advancement of this non-invasive procedure would raise the convenience and feasibility of rebiopsy. Indeed, liquid biopsy using digital PCR has demonstrated its effectiveness to detect T790M mutation after acquired resistance to EGFR-TKIs (22). Liquid biopsy would compensate for the disadvantages of histological rebiopsy in the near future.

Our study includes several limitations. First, it is retrospective in its design and includes a small sample size. However, to the best of our knowledge, our study is the largest to focus on histological rebiopsy. Although potential biases are inevitable, its retrospective nature might well reflect our actual clinical practice. Second, the situation of our Institute may be unique. In Japan, rebiopsy is mostly done by TBB. On the other hand, in western countries, radiologists seem to mostly perform rebiopsy by CTGB. Some of our physicians can carry out TBB, CTGB and USGB by ourselves, and we can easily select the most suitable procedure. Therefore, our data may be unique compared with rebiopsy data from many other institutes.

\section{Conclusion}

Rebiopsy of histological samples can be highly successful and feasible by optimal procedural selection. To select the most suitable procedure, it is important to establish a cooperative system to carry-out optimal procedures. After approval of third-generation EGFR-TKIs, histological rebiopsy to confirm T790M status will become essential in clinical practice for patients after acquired resistance to EGFR-TKIs. Moreover, development of novel therapies such as immunotherapies will encourage histological rebiopsy, even in patients without driver gene alterations. Further studies are warranted to investigate optimizing a histological rebiopsy for better clinical practice.

\section{Conflicts of Interest}

The Authors declare they have no conflicts of interest.

\section{Acknowledgements}

The Authors thank the physicians of KCGH who performed rebiopsies. They also thank David Martin for his writing support.

\section{References}

1 Soda M, Choi YL, Enomoto M, Takada S, Yamashita Y, Ishikawa S, Fujiwara S, Watanabe H, Kurashina K, Hatanaka H, Bando M, Ohno S, Ishikawa Y, Aburatani H, Niki T, Sohara Y, Sugiyama Y and Mano H: Identification of the transforming EML4-ALK fusion gene in non-small-cell lung cancer. Nature 448: 561-566, 2007.

2 Lynch TJ, Bell DW, Sordella R, Gurubhagavatula S, Okimoto RA, Brannigan BW, Harris PL, Haserlat SM, Supko JG, Haluska FG, Louis DN, Christiani DC, Settleman J and Haber DA: Activating mutations in the epidermal growth factor receptor underlying responsiveness of non-small-cell lung cancer to gefitinib. N Engl J Med 350: 2129-2139, 2004.

3 Paez JG, Janne PA, Lee JC, Tracy S, Greulich H, Gabriel S, Herman P, Kaye FJ, Lindeman N, Boggon TJ, Naoki K, Sasaki H, Fujii Y, Eck MJ, Sellers WR, Johnson BE and Meyerson M: EGFR mutations in lung cancer: correlation with clinical response to gefitinib therapy. Science 304: 1497-500, 2004.

4 Lee CK, Wu YL, Ding PN, Lord SJ, Inoue A, Zhou C, Mitsudomi T, Rosell R, Pavlakis N, Links M, Gebski V, Gralla RJ and Yang JC: Impact of specific epidermal growth factor receptor (EGFR) mutations and clinical characteristics on outcomes after treatment with EGFR tyrosine kinase inhibitors versus chemotherapy in EGFR-mutant lung cancer: a metaanalysis. J Clin Oncol 33: 1958-1965, 2005. 
5 Solomon BJ, Mok T, Kim DW, Wu YL, Nakagawa K, Mekhail T, Felip E, Cappuzzo F, Paolini J, Usari T, Iyer S, Reisman A, Wilner KD, Tursi J, Blackhall F; PROFILE 1014 Investigators: First-line crizotinib versus chemotherapy in ALK-positive lung cancer. N Engl J Med 371: 2167-2177, 2014.

6 Pao W, Miller VA, Politi KA, Riely GJ, Somwar R, Zakowski MF, Kris $\mathrm{MG}$ and Varmus $\mathrm{H}$ : Acquired resistance of lung adenocarcinomas to gefitinib or erlotinib is associated with a second mutation in the EGFR kinase domain. PLoS Med 2: e73, 2005.

7 Kobayashi S, Boggon TJ, Dayaram, Jänne PA, Kocher O, Meyerson M, Johnson BE, Eck MJ, Tenen DG and Halmos B: EGFR mutation and resistance of non-small-cell lung cancer to gefitinib. N Engl J Med 352: 786-792, 2005.

8 Engelman JA, Zejnullahu K, Mitsudomi T, Song Y, Hyland C, Park JO, Lindeman N, Gale CM, Zhao X, Christensen J, Kosaka T, Holmes AJ, Rogers AM, Cappuzzo F, Mok T, Lee C, Johnson BE, Cantley LC and Jänne PA: MET amplification leads to gefitinib resistance in lung cancer by activating ERBB3 signaling. Science 316: 1039-1043, 2007.

9 Sequist LV, Waltman BA, Dias-Santagata D, Digumarthy S, Turke AB, Fidias P, Bergethon K, Shaw AT, Gettinger S, Cosper AK, Akhavanfard S, Heist RS, Temel J, Christensen JG, Wain JC, Lynch TJ, Vernovsky K, Mark EJ, Lanuti M, Iafrate AJ, Mino-Kenudson $M$ and Engelman JA: Genotypic and histological evolution of lung cancers acquiring resistance to EGFR inhibitors. Sci Transl Med 3: 75ra26, 2011.

10 Yu HA, Arcila ME, Rekhtman N, Sima CS, Zakowski MF, Pao W, Kris MG, Miller VA, Ladanyi M and Riely GJ: Analysis of tumor specimens at the time of acquired resistance to EGFRTKI therapy in 155 patients with EGFR-mutant lung cancers. Clin Cancer Res 19: 2240-2247, 2013.

11 Jänne PA, Yang JC, Kim DW, Planchard D, Ohe Y, Ramalingam SS, Ahn MJ, Kim SW, Su WC, Horn L, Haggstrom D, Felip E, Kim JH, Frewer P, Cantarini M, Brown KH, Dickinson PA, Ghiorghiu S and Ranson M: AZD9291 in EGFR inhibitor-resistant non-small-cell lung cancer. N Engl J Med 372: 1689-1699, 2015.

12 Sequist LV, Soria JC, Goldman JW, Wakelee HA, Gadgeel SM, Varga A, Papadimitrakopoulou V, Solomon BJ, Oxnard GR, Dziadziuszko R, Aisner DL, Doebele RC, Galasso C, Garon EB, Heist RS, Logan J, Neal JW, Mendenhall MA, Nichols S, Piotrowska Z, Wozniak AJ, Raponi M, Karlovich CA, Jaw-Tsai S, Isaacson J, Despain D, Matheny SL, Rolfe L, Allen AR and Camidge DR: Rociletinib in EGFR-mutated non-small-cell lung cancer. N Engl J Med 372: 1700-1709, 2015.

13 Brahmer J, Reckamp KL, Baas P, Crinò L, Eberhardt WE, Poddubskaya E, Antonia S, Pluzanski A, Vokes EE, Holgado E, Waterhouse D, Ready N, Gainor J, Arén Frontera O, Havel L, Steins M, Garassino MC, Aerts JG, Domine M, Paz-Ares L, Reck M, Baudelet C, Harbison CT, Lestini B and Spigel DR: Nivolumab versus Docetaxel in Advanced Squamous-Cell NonSmall-Cell Lung Cancer. N Engl J Med 373: 123-135, 2015.

14 Borghaei H, Paz-Ares L, Horn L, Spigel DR, Steins M, Ready NE, Chow LQ, Vokes EE, Felip E, Holgado E, Barlesi F, Kohlhäufl M, Arrieta $\mathrm{O}$, Burgio MA, Fayette J, Lena H, Poddubskaya E, Gerber DE, Gettinger SN, Rudin CM, Rizvi N, Crinò L, Blumenschein GR Jr., Antonia SJ, Dorange C, Harbison CT, Graf Finckenstein F and Brahmer JR: Nivolumab versus Docetaxel in Advanced Nonsquamous Non-Small-Cell Lung Cancer. N Engl J Med 373: 1627-1639, 2015.
15 Herbst RS, Baas P, Kim DW, Felip E, Pérez-Gracia JL, Han JY, Molina J, Kim JH, Arvis CD, Ahn MJ, Majem M, Fidler MJ, de Castro G Jr., Garrido M, Lubiniecki GM, Shentu Y, Im E, Dolled-Filhart $\mathrm{M}$ and Garon EB: Pembrolizumab versus docetaxel for previously treated, PD-L1-positive, advanced nonsmall-cell lung cancer (KEYNOTE-010): a randomised controlled trial. Lancet 387: 1540-1550, 2016.

16 Rittmeyer A, Barlesi F, Waterkamp D, Park K, Ciardiello F, von Pawel J, Gadgeel SM, Hida T, Kowalski DM, Dols MC, Cortinovis DL, Leach J, Polikoff J, Barrios C, Kabbinavar F, Frontera OA, De Marinis F, Turna H, Lee JS, Ballinger M, Kowanetz M, He P, Chen DS, Sandler A, Gandara DR; OAK Study Group.: Atezolizumab versus docetaxel in patients with previously treated non-small-cell lung cancer (OAK): a phase 3, open-label, multicentre randomised controlled trial. Lancet 389: 255-265, 2017.

17 Fehrenbacher L, Spira A, Ballinger M, Kowanetz M, Vansteenkiste J, Mazieres J, Park K, Smith D, Artal-Cortes A, Lewanski C, Braiteh F, Waterkamp D, He P, Zou W, Chen DS, Yi J, Sandler A, Rittmeyer A; POPLAR Study Group.: Atezolizumab versus docetaxel for patients with previously treated non-small-cell lung cancer (POPLAR): a multicentre, open-label, phase 2 randomised controlled trial. Lancet 30 : 1837-1846, 2016.

18 Gainor JF, Shaw AT, Sequist LV, Fu X, Azzoli CG, Piotrowska Z, Huynh TG, Zhao L, Fulton L, Schultz KR, Howe E, Farago AF, Sullivan RJ, Stone JR, Digumarthy S, Moran T, Hata AN, Yagi Y, Yeap BY, Engelman JA and Mino-Kenudson M: EGFR mutations and ALK rearrangements are associated with low response rates to PD-1 pathway blockade in non-small cell lung cancer: a retrospective analysis. Clin Cancer Res 22: 4585-4593, 2016.

19 Nagai Y, Miyazawa H, Huqun, Tanaka T, Udagawa K, Kato M, Fukuyama S, Yokote A, Kobayashi K, Kanazawa M and Hagiwara K: Genetic heterogeneity of the epidermal growth factor receptor in non-small cell lung cancer cell lines revealed by a rapid and sensitive detection system, the peptide nucleic acidlocked nucleic acid PCR clamp. Cancer Res 65: 7276-7282, 2005.

20 Kosaka T, Yatabe Y, Endoh H, Yoshida K, Hida T, Tsuboi M, Tada H, Kuwano H and Mitsudomi T: Analysis of epidermal growth factor receptor gene mutation in patients with non-small cell lung cancer and acquired resistance to gefitinib. Clin Cancer Res 12: 5764-5769, 2006.

21 Tomiyama N, Yasuhara Y, Nakajima Y, Adachi S, Arai Y, Kusumoto M, Eguchi K, Kuriyama K, Sakai F, Noguchi M, Murata K, Murayama S, Mochizuki T, Mori K and Yamada K: CT-guided needle biopsy of lung lesions: A survey of severe complication based on 9783 biopsies in Japan. Eur J Radiol 59: 60-64, 2006.

22 Takahama T, Sakai K, Takeda M, Azuma K, Hida T, Hirabayashi M, Oguri T, Tanaka H, Ebi N, Sawa T, Bessho A, Tachihara M, Akamatsu H, Bandoh S, Himeji D, Ohira T, Shimokawa M, Nakanishi Y, Nakagawa K and Nishio K: Detection of the T790M mutation of EGFR in plasma of advanced non-small cell lung cancer patients with acquired resistance to tyrosine kinase inhibitors (West Japan oncology group 8014LTR study). Oncotarget 7: 58492-58499, 2016.

Received January 20, 2017

Revised March 30, 2017

Accepted March 31, 2017 